Article

\title{
Analytic Hierarchy Process-Based Analysis to Determine the Barriers to Implementing a Material Efficiency Strategy: Electrical and Electronics' Companies in the Malaysian Context
}

\author{
Fu Haw Ho ${ }^{1,2, *}$, Salwa Hanim Abdul-Rashid ${ }^{1, *}$ and Raja Ariffin Raja Ghazilla ${ }^{1}$ \\ 1 Centre for Product Design and Manufacturing, Department of Mechanical Engineering, \\ Faculty of Engineering, University of Malaya, 50603 Kuala Lumpur, Malaysia; r_ariffin@um.edu.my \\ 2 Department of Manufacturing and Industrial Engineering, Faculty of Mechanical and Manufacturing \\ Engineering, Universiti Tun Hussein Onn Malaysia, 86400 Johor, Malaysia \\ * Correspondence: eric_ho@gmx.com (F.H.H.); salwa_hanim@um.edu.my (S.H.A.-R.); \\ Tel.: +607-453-7700 (F.H.H.); +603-7967-7625 (S.H.A.-R.); \\ Fax: +607-453-6868 (F.H.H.); +603-7967-5317 (S.H.A.-R.)
}

Academic Editor: Patrick A. Wäger

Received: 15 May 2016; Accepted: 4 October 2016; Published: 15 October 2016

\begin{abstract}
Material efficiency is one of the most important strategies for helping manufacturing companies achieve sustainability in their production activities. However, there are many barriers to the implementation of material efficiency strategies in the manufacturing processes and overall business operations. The aim of this study is to identify and evaluate the barriers faced by Electrical and Electronics (E\&E) manufacturing companies in Malaysia in implementing material efficiency strategies. A mixed-mode research method was employed to collect data from these companies. Semi-structured interviews were used to identify the barriers faced by the Malaysian Electrical and Electronics (E\&E) industry, while an Analytic Hierarchy Process (AHP) survey was utilized to determine the importance of each barrier. Seven companies participated in the semi-structured interviews, and 18 companies took part in the AHP survey. Nine barriers were generated from analysis of the interviews, and were then ranked by priority using the AHP method. These important findings could be used as a guide for E\&E companies in managing or overcoming barriers during the implementation of material efficiency strategies and other sustainable manufacturing activities.
\end{abstract}

Keywords: analytic hierarchy process; electrical and electronics industry; material efficiency; multi-criteria decision-making; sustainable manufacturing

\section{Introduction}

Over the past few decades, an increasing number of manufacturing companies have undertaken various environmental strategies to enhance resource utilization and to reduce waste generation, such as energy efficiency, 3R strategy (reduce, reuse, recycle), waste minimization, resource efficiency, and material efficiency. Unlike other environmental strategies, the material efficiency strategy emphasizes the reduction of material intake, while, at the same time, minimizes the generation of industrial waste and the environmental impact. For example, manufacturers using green materials emphasize product light weighting and product design for longer life [1-3]. These practices can contribute to the implementation of material efficiency in manufacturing. Although there is a growing trend in material efficiency, its implementation and practice are still limited for various reasons $[4,5]$. One such reason is the existence of barriers that hinder the implementation of this strategy, which could then result in manufacturers being unable to optimize the use of their raw materials and improve their business 
performance. Thus, by identifying and understanding these barriers, manufacturers can undertake appropriate countermeasures to optimize their raw material usage easily and effectively [6].

In Malaysia, the manufacturing industry is a significant contributor to the economic development of the country. Within this industry, the electrical and electronics (E\&E) sector forms a large percentage of the manufacturing industry compared to the petroleum, rubber, and paper sub-sectors [7]. Data from the Ministry of International Trade and Industry [8] have shown that the E\&E sector has been the largest contributor to the total number of exported products over the past three years (2015: $57.8 \%$; 2014: 52.27\%; and 2013: 32.8\%).

However, the escalating growth of the E\&E industry has created numerous challenges to manufacturers, such as the increased consumption of resources and the generation of hazardous waste. For instance, the global consumption of raw materials, such as rare earth metals for E\&E goods, is estimated at 136,000 metric tons [9], and is predicted to grow by $5 \%$ each year [10]. Consequently, rare earth metals could become scarce due to high consumption by the electronics sector [9]. As for waste generation, these waste materials are generated as by-products during the production process and during the product end of life phase. The inefficient use of these materials is detrimental to the environment as these hazardous substances are difficult to reuse and reprocess for other purposes [11]. In most cases, such waste ends up in landfills, especially in developing countries that lack awareness and appropriate technology for recycling [11]. Therefore, the implementation of material efficiency to address these challenges is of the utmost importance. In addition, proper determination and understanding of the barriers faced by these companies is required before appropriate solutions can be proposed.

This paper is divided into five sections. The first section covers the introduction to the research. The subsequent section reviews the barriers that influence efficient material use in different manufacturing sectors. Section 3 discusses the research methodology used and provides an analysis of the semi-structured interviews and Analytic Hierarchy Process (AHP) survey. Section 4 presents and discusses the results gathered from the data collection. The final section concludes the paper, describes the potential implications for this research and offers suggestions for future research.

\section{Literature Review}

\subsection{Material Efficiency}

According to Abdul Rashid [12], material efficiency is a strategy that not only prevents materials from becoming waste but also addresses pollution due to the type of material used and adds value to products or services through the efficient use and the right selection of materials. Worrell et al. [13] broadly defined material efficiency as "reducing the consumption of primary materials without affecting the level of human activities qualitatively". Peck and Chipman [3] defined material efficiency in industrial production as the amount of a particular material needed to produce a particular product.

Abdul Rashid [12] claimed that material efficiency is a collection of manufacturing practices that are actively coordinated and implemented with the aim of:

- Using less materials per product made, and/or;

- Generating less waste per product, and/or;

- Using materials that use less energy to make each product, and/or;

- Selecting materials that reduce the impact on the environment (e.g., less toxic, recoverable, recyclable, and disposable).

This definition by Abdul Rashid [12] encompasses much more than a simple input/output ratio as it also takes into account additional concerns, such as energy, toxicity and other environmental impacts. In order to achieve material efficiency, product design and manufacturing activities are two key areas that should be considered $[1,2,14]$. In product design, examples of material efficiency strategies include designing for longer life, designing for reuse, multiple functions per unit design, designing for serviceability, material substitution, and designing for light-weighting. While, in the 
manufacturing process, the strategies consist of yield improvement, batch processing, energy efficiency, use of pre-cut materials, and minimizing secondary processes. The importance of incorporating material efficiency in manufacturing processes has been strongly acknowledged by both academics and industrial practitioners $[2,4,5,15,16]$. However, the existence of several barriers has limited the adoption of this strategy in the actual practices. A review of the existing literature may identify a significant number of these barriers. According to Hillary [17], there are two types of barrier that influence environmental practices-internal barriers and external barriers. Internal barriers originate from the organization itself whereas external barriers come from outside the organization. The surveyed list of barriers is shown in Table 1.

\subsection{Internal Barriers}

\subsubsection{Lack of Awareness}

Some manufacturing sectors still perceive that the resources available are cheap and abundant [1], and thus, for them, practicing material efficiency is considered less important $[2,18]$. According to Halme et al. [18], compared to other environmental strategies, adopting material efficiency does not have any significant impact on business competency or increase the reputation of the company. As a result, awareness of material efficiency among manufacturers is still at a low level.

Table 1. Summary of barriers to practicing material efficiency strategy.

\begin{tabular}{|c|c|c|c|}
\hline & Barrier & Description & References \\
\hline \multirow{4}{*}{$\begin{array}{l}\text { Internal } \\
\text { barrier }\end{array}$} & $\begin{array}{c}\text { Lack of } \\
\text { awareness }\end{array}$ & - Poor environmental awareness & {$[1,3]$} \\
\hline & $\begin{array}{l}\text { Implementation } \\
\text { cost }\end{array}$ & $\begin{array}{l}\text { - High cost to invest in technology } \\
\text { - Unwilling to invest in unproven strategy } \\
\text { - High cost to obtain environmental permits } \\
\text { - High management cost (e.g., training) }\end{array}$ & $\begin{array}{c}{[6,19]} \\
{[6,19,20]} \\
{[6,19]} \\
{[1,2,16]} \\
\end{array}$ \\
\hline & $\begin{array}{l}\text { Product design } \\
\text { restriction }\end{array}$ & $\begin{array}{l}\text { - Restriction on type of material used } \\
\text { - Restriction on product design changes }\end{array}$ & $\begin{array}{c}{[1,3,12,16]} \\
{[1,3]}\end{array}$ \\
\hline & $\begin{array}{l}\text { Lack of } \\
\text { information } \\
\text { and knowledge }\end{array}$ & $\begin{array}{l}\text { - Lack of technical knowledge } \\
\text { - Lack of support (e.g., policies, guidance) } \\
\text { - Limited exposure to material efficiency information/concept }\end{array}$ & $\begin{array}{c}{[4,6]} \\
{[3,21]} \\
{[6,20,22,23]}\end{array}$ \\
\hline \multirow{4}{*}{$\begin{array}{l}\text { External } \\
\text { barrier }\end{array}$} & Regulation & $\begin{array}{l}\text { - International environmental regulation and legislation } \\
\text { - Lack of local support on regulation/legislation }\end{array}$ & $\begin{array}{c}{[4,6,25]} \\
{[2,13,25]}\end{array}$ \\
\hline & $\begin{array}{l}\text { External } \\
\text { support }\end{array}$ & $\begin{array}{l}\text { - Lack of governmental support (e.g., certificate, subsidy, incentives) } \\
\text { - } \quad \text { Lack of material efficiency experts } \\
\text { - } \quad \text { Limited support from other sectors (e.g., recycler, recycling technology) }\end{array}$ & $\begin{array}{c}{[1]} \\
{[2]} \\
{[1,4,6]}\end{array}$ \\
\hline & $\begin{array}{l}\text { Supplier and } \\
\text { supply chain } \\
\text { constraint }\end{array}$ & $\begin{array}{l}\text { - Unsupportive supplier } \\
\text { - Limited green suppliers / capable suppliers with technology } \\
\text { - Lack of suppliers that can support material efficiency strategies } \\
\text { - Overseas suppliers face difficulty in supporting material efficiency strategies } \\
\text { (e.g., comply with different regulations, inability to control sourcing, etc.) }\end{array}$ & $\begin{array}{l}{[1,25]} \\
{[17,22-24]} \\
{[6]} \\
{[22]}\end{array}$ \\
\hline & $\begin{array}{l}\text { Customer } \\
\text { requirements }\end{array}$ & $\begin{array}{l}\text { - Lack of green product demand } \\
\text { - Little economic pressure } \\
\text { - Rapid product changes }\end{array}$ & $\begin{array}{l}{[1,3]} \\
{[3,6]} \\
{[25]}\end{array}$ \\
\hline
\end{tabular}

\subsubsection{Unwillingness to Change}

There are unavoidable changes that must be faced by companies, such as the rise in raw material prices and the increase in manufacturing solid waste [3,6]. Many manufacturing companies, especially small and medium-sized enterprises (SMEs), are not ready to respond to these changes or able to embed them into existing manufacturing activities [1,6]. Some manufacturers fail to see the cost benefit of implementing material efficiency, and, therefore, consider material efficiency strategies as 
an optional choice. Most of these companies react by transferring the increase in raw material prices to the customers $[1,3]$. Furthermore, some companies, especially SMEs, are reluctant to change their existing and familiar manufacturing processes to something new that requires significant time and financial investment $[2,4,15,16]$.

\subsubsection{Implementation Cost}

Implementing a new strategy into a business requires the company to invest. Although obtaining advanced machinery offers better efficiency in the manufacturing process due to higher speed, lower energy consumption, and better processing capability than existing equipment, the lack of unproven results in terms of direct cost savings discourages manufacturers from investing capital and resources in a material efficiency strategy $[6,20]$.

\subsubsection{Product Design Restriction}

Product design restriction is another barrier that limits manufacturing companies from practicing a material efficiency strategy effectively $[1,3,16]$. Material substitution is not suitable for every product as it can impact on product safety and functionality $[1,3]$. For example, certain critical parts used in aerospace applications require the usage of high performance materials. Similarly, medical devices require the use of non-toxic and high quality virgin materials. Allwood et al. [1] highlighted that changing a product design is complex and difficult because it consists not only of material replacement, but also impacts on the manufacturing process and other aspects, such as product reliability.

\subsubsection{Lack of Information and Knowledge}

Allwood et al. [4] discovered that manufacturers in developing nations lack the necessary technical knowledge to practice material efficiency strategies. According to Lilja [2], and Worrell et al. [13], most material efficiency strategies are widely practiced in developed nations but their efforts are less supported by national policies and material efficiency experts [3,21]. The research conducted by Pajunen et al. [6] shows that many manufacturing industries face similar issues: they will not practice strategies about which they have no knowledge. The limited information available concerning material efficiency has constrained manufacturers' initiatives to practice material efficiency strategies $[20,22,23]$. For example, in product design, a designer that lacks the knowledge to design a product using a 'sense of simplicity' leads to the wastage of raw materials $[1,4]$.

\subsubsection{Technology Limitation}

A lack of available technology can limit the practice of material efficiency $[4,6,24]$. This can be illustrated by the lack of technology to process by-products within the manufacturing sector. The unavailability of cheap and affordable new technology also prevents a company from processing raw materials efficiently $[13,20]$. Such limitations in existing recycling technology may discourage manufacturers from designing their product using material efficiency strategies $[4,6]$.

\subsection{External Barriers}

\subsubsection{Regulation/Legislation}

Environmental legislation can work as a driver or a barrier in the implementation of any strategy $[4,6,25]$. Many directives and legislations have been set to monitor and prevent environmental problems, such as the Restriction on Hazardous Substances (RoHS) directive, and Waste from Electrical and Electronic Waste (WEEE) directive. Such stringent legislation and standards could work as a guide for the manufacturing industry for the management and proper disposal of production waste. Nevertheless, it has been shown by past studies that manufacturers are reluctant to comply with environmental policies due to the complexities during implementation [6]. For instance, the difficulty in acquiring green materials that may vary in their specification due to the differing environmental 
policies of different countries, such as the mixture of recycled material with virgin materials, toxic free materials, fully biodegradable and fully recyclable materials.

\subsubsection{Lack of External Support}

The lack of external support and encouragement from the government to encourage and provide certification, policies, subsidies, and incentives has hampered manufacturers from practicing material efficiency strategies [1]. In addition, the lack of material efficiency experts is another reason for the slow adoption of a material efficiency strategy [2]. Furthermore, the lack of support from product recyclers has also delayed the use of material efficiency strategies among manufacturers [1]. In some developing countries, the inability of technology and service suppliers to provide and support advanced technology to manufacturers also hinders initiatives for achieving material efficiency, especially when the available machine capacity is less capable of optimally machining the raw materials. For example, the use of a Computerized Numerical Control (CNC) laser machine could reduce material wastage when compared to conventional machining, particularly in optimizing the arrangement of the parts to be machined.

\subsubsection{Supplier and Supply Chain}

Uncooperative suppliers or subcontractors also discourage manufacturers from using materials efficiently $[1,25]$. Another issue is the limited number of green suppliers capable of supplying recyclable raw materials to the manufacturers [20]. Furthermore, most suppliers are less capable of supplying the requested raw materials due to limitations in the technology to produce green materials [26,27]. Pajunen et al. [6] mentioned that the lack of green material suppliers could discourage manufacturers' initiatives to practice material efficiency. Abdul Rashid and Evans [25] suggested that one of the reasons is due to the difficulty in compliance with the regulations and standards.

\subsubsection{Customer Requirement}

The lack of demand for products made from recycled materials has resulted in many manufacturers forgoing the use of recycled materials as a source for their products [1,3]. In addition, economic pressure can also discourage manufacturers from practicing material efficiency [3,6], especially since green products are considered as being more expensive than their normal counterparts. The current trend in product requirements focuses on energy efficiency instead of material efficiency, and, therefore, in some manufacturing industries, material efficiency receives limited attention as it is difficult to achieve and practice due to the rapid changes in product requirements, especially in the E\&E sector [28] where some products are designed with short life cycles due to the swift changes in trends or fashion $[8,14]$.

\section{Research Method}

In this study, a mixed-mode research method was used for data collection [29]. Two phases of data collection were conducted: (Phase 1) Qualitative study using semi-structured interviews to gain insights into the material efficiency strategies employed by E\&E manufacturers; and (Phase 2) Quantitative study using an AHP survey to determine the weight of the priorities in respect of the barriers that were determined in phase one. The research flow is illustrated in Figure 1. 


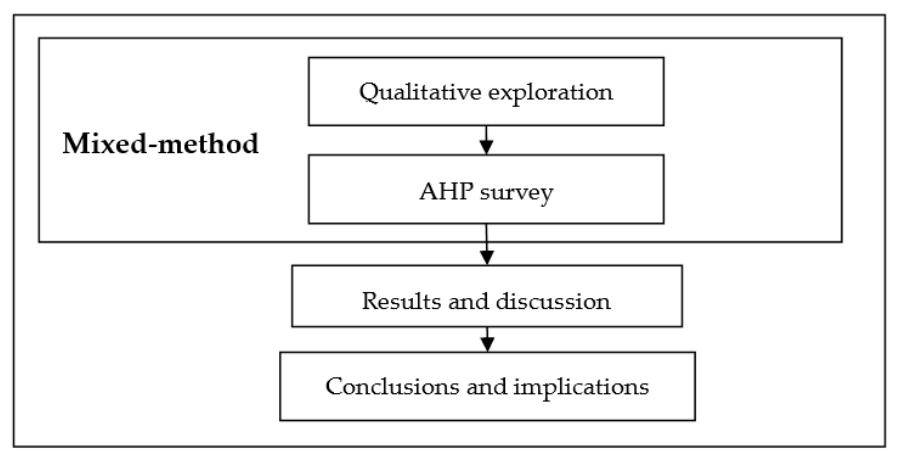

Figure 1. Research methods flow chart.

\subsection{Semi-Structured Interviews}

The first phase of the data collection was carried out through multiple case studies [30]. Semi-structured interviews were chosen to enable insightful data exploration within the pre-set boundaries [30,31]. A set of questions was prepared and the interviewer steered the conversation around the pre-determined questions listed in Appendix A. The recruitment of the companies to participate in the interview sessions was carefully designed to ensure that the company and personnel selected were relevant to the study. Examples of the selection criteria were only selecting E\&E companies involved in manufacturing, and personnel with at least 5 years working experience. The list of companies was obtained from the directory of the Federation of Manufacturing Malaysia 2013. The recruitment process was conducted using emails and phone calls. In total, seven companies agreed to participate in the interview sessions, as listed in Table 2. These companies were large sized companies with more than 250 employees. The key-informants or representatives from these companies were the production managers, packaging managers, design engineers, senior engineers and Environmental-Health-Safety (EHS) managers. All the participating companies were labelled $\mathrm{C} 1$ to $\mathrm{C} 7$ for data confidentiality. Face-to-face interview sessions were then conducted, averaging 50 minutes each. The recorded interviews were transcribed verbatim and analyzed using thematic analysis, which was used to generate a list of themes [32]. In generating a theme, the related verbatim quotes were first identified and selected. From the key meaning of the quote, an appropriate code was assigned to identify the important theme of the issue. Codes that fell under a similar category were grouped, and the final codes were obtained to represent the barriers. These final codes were then named using a suitable theme. Figure 2 shows an example of the theme formation extracted from several different quotes. Necessary steps were also taken to ensure the reliability and quality in the results obtained, such as peer checks and audit trails.

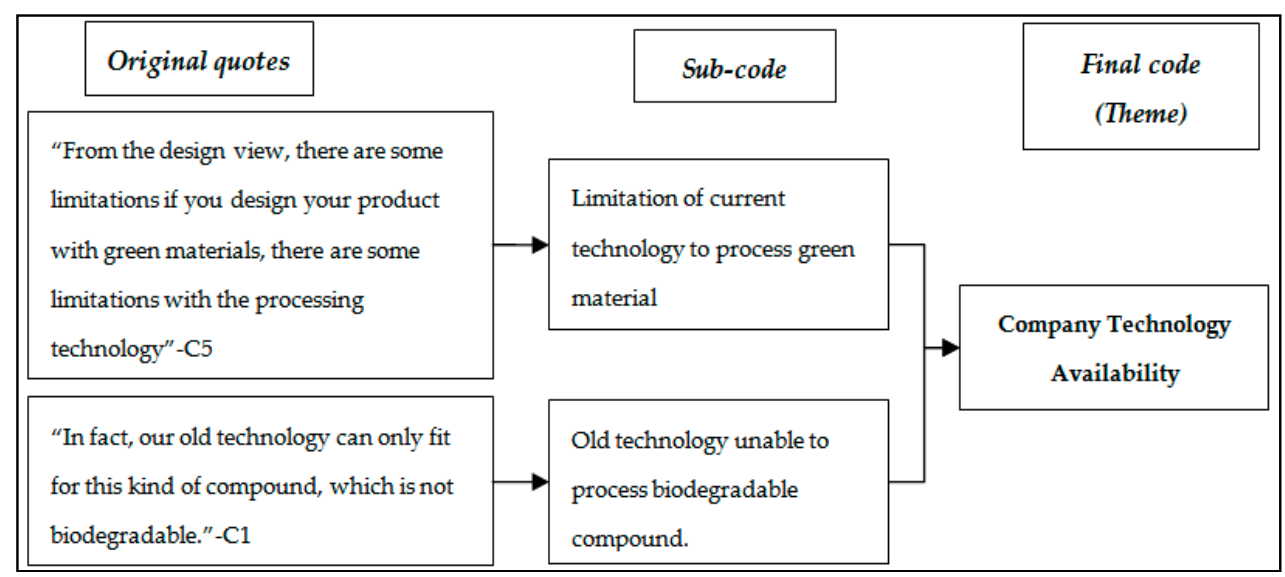

Figure 2. Formation of barrier themes. 
Table 2. List of case study organizations in a Malaysian Context.

\begin{tabular}{cccc}
\hline Company & Country of Origin, Size & Example Product/Service & Interviewee \\
\hline C1 & Germany, Large & $\begin{array}{c}\text { Integrated circuits, electronic } \\
\text { components for automobiles }\end{array}$ & $\begin{array}{c}\text { Senior Engineer } \\
\text { (Quality control) }\end{array}$ \\
\hline C2 & US, Large & $\begin{array}{c}\text { Circuit design, walkie-talkies, } \\
\text { communication devices }\end{array}$ & Material Specialist \\
\hline C3 & US, Large & $\begin{array}{c}\text { Integrated circuits, circuit } \\
\text { design, electronic components }\end{array}$ & $\begin{array}{c}\text { Packaging Department } \\
\text { Director, Senior engineer }\end{array}$ \\
\hline C4 & Malaysia, Large & $\begin{array}{c}\text { Integrated circuits, circuit } \\
\text { design and assembly }\end{array}$ & $\begin{array}{c}\text { Environmental, Health, } \\
\text { and Safety (EHS) Manager }\end{array}$ \\
\hline C5 & US, Large & $\begin{array}{c}\text { Solar cells, solar panels } \\
\text { TV brackets, Assembly of TV } \\
\text { products, Printed Circuit } \\
\text { boards, circuit design }\end{array}$ & $\begin{array}{c}\text { Packaging manager } \\
\text { (Quality control) }\end{array}$ \\
\hline C7 & Japan, Large & $\begin{array}{c}\text { TV brackets, Assembly of TV } \\
\text { products, Printed Circuit } \\
\text { boards, circuit design }\end{array}$ & $\begin{array}{c}\text { Senior designer } \\
\text { (Design engineer) }\end{array}$ \\
\hline
\end{tabular}

\subsection{AHP Survey}

In the second phase of data collection, the AHP technique was used to determine the priority weight of the list of barriers obtained in the qualitative data collection stage. AHP is a method for multi-criteria decision-making in which the relative weights of possible decision alternatives or outcomes are given a functional value based on a mathematical representation of pairwise comparisons [33]. The benefit of AHP is to structure a multi-criteria decision-making problem into a hierarchy that shows the relationships between the goal, criteria, sub-criteria and alternatives [34]. The criteria refer to the higher group of categories, while the sub-criteria denote the lower group of categories that are the broken down from the criteria. In this study, the criteria are the internal and external barriers; one example of the sub-criteria for the internal barriers is the implementation cost. The hierarchy of the criteria and sub-criteria arrangement is shown in Figure 3. By using this approach, the inherent answers given by both the researchers and the participants of the AHP can be reduced. In this study, an AHP framework and AHP survey were developed based on the barriers that were generated from the literature and qualitative study. In the AHP survey instrument, assessment of each pairwise scoring was conducted. Each of the pairwise comparisons was evaluated based on the given scales (from 1 to 9) [34]. A scale of 1 represents the lowest score or equal weight of that pairwise, while a scale of 9 represents the highest score of the pairwise comparison.

The recruitment of the AHP respondents was done by email and phone calls to key decision-makers and experienced personnel of selected E\&E companies. Eighteen key informants from eighteen E\&E companies in Peninsular Malaysia were selected for the AHP survey, which was conducted at the convenience of the respondents. These companies included large sized companies ( $>250$ employees) and also medium sized companies $(250>$ employee $>100)$. The chosen respondents came from a variety of E\&E companies ranging from consumer electronics, electronic components, industrial electronics and electrical companies. To ensure the quality and reliability of the data collected, only experienced management personnel were recruited, such as production managers, department directors, principal engineers, EHS managers and lean managers. The details of these companies and the positions of the key-informants are presented in Table 3. To obtain the weightage for the barrier for implementing material strategies, the collected data were analyzed using Expert Choice V.11 software (Expert Choice Inc., Pittsburgh, PA, USA). Five steps of analysis were conducted before the final importance weights were obtained [34]: 
(1) Constructing the pairwise comparison matrix for each key-informant

(2) Assessing the consistency of the pairwise judgment (accepted Inconsistency Ratio (IR) < 0.1; request key-informant to redo the pairwise items with IR >0.1)

(3) Constructing the geometric mean evaluation (combine all 18 sets of results)

(4) Computing the importance weights for the local and global vectors (normalized eigenvector)

(5) Displaying the priorities for the evaluated criteria for the barriers

Table 3. AHP respondent details.

\begin{tabular}{|c|c|c|c|c|}
\hline Company & Type of E\&E & $\begin{array}{l}\text { Country of } \\
\text { Origin, Size }\end{array}$ & Example of Product/Service & AHP Participant \\
\hline AHP 1 & $\begin{array}{c}\text { Electronic } \\
\text { components }\end{array}$ & US, Large & $\begin{array}{c}\text { Integrated circuits } \\
\text { (e.g., electronic chipsets) }\end{array}$ & Packaging manager \\
\hline AHP 2 & $\begin{array}{l}\text { Consumer } \\
\text { electronics }\end{array}$ & Japan, Large & $\begin{array}{l}\text { Audio and video products } \\
\text { (e.g., TV) }\end{array}$ & $\begin{array}{l}\text { Senior engineer } \\
\text { (team leader) }\end{array}$ \\
\hline AHP 3 & $\begin{array}{l}\text { Consumer } \\
\text { electronics }\end{array}$ & $\begin{array}{l}\text { The Netherlands, } \\
\text { Large }\end{array}$ & $\begin{array}{c}\text { Audio and video products } \\
\text { (e.g., TV) }\end{array}$ & $\begin{array}{l}\text { Senior designer } \\
\text { (team leader) }\end{array}$ \\
\hline AHP 4 & $\begin{array}{l}\text { Electronic } \\
\text { components }\end{array}$ & $\begin{array}{l}\text { Malaysia, } \\
\text { Medium }\end{array}$ & Electronic components & Production manager \\
\hline AHP 5 & $\begin{array}{l}\text { Industrial } \\
\text { electronics }\end{array}$ & US, Large & $\begin{array}{l}\text { Computer devices } \\
\text { (e.g., hard disks) }\end{array}$ & $\begin{array}{l}\text { Senior engineer } \\
\text { (team leader) }\end{array}$ \\
\hline AHP 6 & $\begin{array}{l}\text { Electronic } \\
\text { components }\end{array}$ & Germany, Large & $\begin{array}{c}\text { Design and manufacturing } \\
\text { of electronic circuits }\end{array}$ & $\begin{array}{l}\text { Electronics designer } \\
\text { (team leader) }\end{array}$ \\
\hline AHP 7 & $\begin{array}{l}\text { Consumer } \\
\text { electronics }\end{array}$ & Singapore, Large & $\begin{array}{c}\text { Communications devices } \\
\text { (e.g., telephones) }\end{array}$ & Program engineer \\
\hline AHP 8 & $\begin{array}{l}\text { Consumer } \\
\text { electronics }\end{array}$ & Singapore, Large & $\begin{array}{l}\text { Printing devices } \\
\text { (e.g., printers) }\end{array}$ & $\begin{array}{l}\text { Senior engineer } \\
\text { (team leader) }\end{array}$ \\
\hline AHP 9 & $\begin{array}{l}\text { Industrial } \\
\text { electronics }\end{array}$ & Japan, Large & $\begin{array}{l}\text { Computer products } \\
\text { (e.g., desktop keyboards) }\end{array}$ & Logistics manager \\
\hline AHP 10 & $\begin{array}{l}\text { Electronic } \\
\text { components }\end{array}$ & US, Large & $\begin{array}{c}\text { Integrated circuits } \\
\text { (e.g., electronic chipsets) }\end{array}$ & Senior engineer \\
\hline AHP 11 & Electrical & US, Large & $\begin{array}{l}\text { Electrical appliances } \\
\text { (e.g., microwaves) }\end{array}$ & Lean manager \\
\hline AHP 12 & $\begin{array}{l}\text { Consumer } \\
\text { electronics }\end{array}$ & US, Large & $\begin{array}{c}\text { Communication devices } \\
\text { (e.g., walkie talkies) }\end{array}$ & Lean manager \\
\hline AHP 13 & $\begin{array}{c}\text { Electronic } \\
\text { components }\end{array}$ & Malaysia, Large & $\begin{array}{l}\text { Integrated circuits } \\
\text { (e.g., electronic chips) }\end{array}$ & Production manager \\
\hline AHP 14 & $\begin{array}{l}\text { Industrial } \\
\text { electronics }\end{array}$ & Germany, Large & $\begin{array}{l}\text { Integrated circuits and } \\
\text { electronic devices (e.g., ABS } \\
\text { electronic controllers) }\end{array}$ & $\begin{array}{l}\text { Senior engineer } \\
\text { (team leader) }\end{array}$ \\
\hline AHP 15 & Electrical & Japan, Large & $\begin{array}{l}\text { Air-conditioning systems } \\
\text { (air-conditioning } \\
\text { compressors, blowers) }\end{array}$ & $\begin{array}{l}\text { Environmental, } \\
\text { Safety, and Health } \\
\text { Manager }\end{array}$ \\
\hline AHP 16 & $\begin{array}{l}\text { Industrial } \\
\text { electronics }\end{array}$ & US, Large & $\begin{array}{l}\text { Electronic devices for } \\
\text { experimental lab use }\end{array}$ & Operations manager \\
\hline AHP 17 & Electrical & US, Large & Solar cells & Packaging manager \\
\hline AHP 18 & $\begin{array}{l}\text { Consumer } \\
\text { electronics }\end{array}$ & US, Large & $\begin{array}{l}\text { Communication devices } \\
\text { (e.g., telephone) }\end{array}$ & Principal designer \\
\hline
\end{tabular}




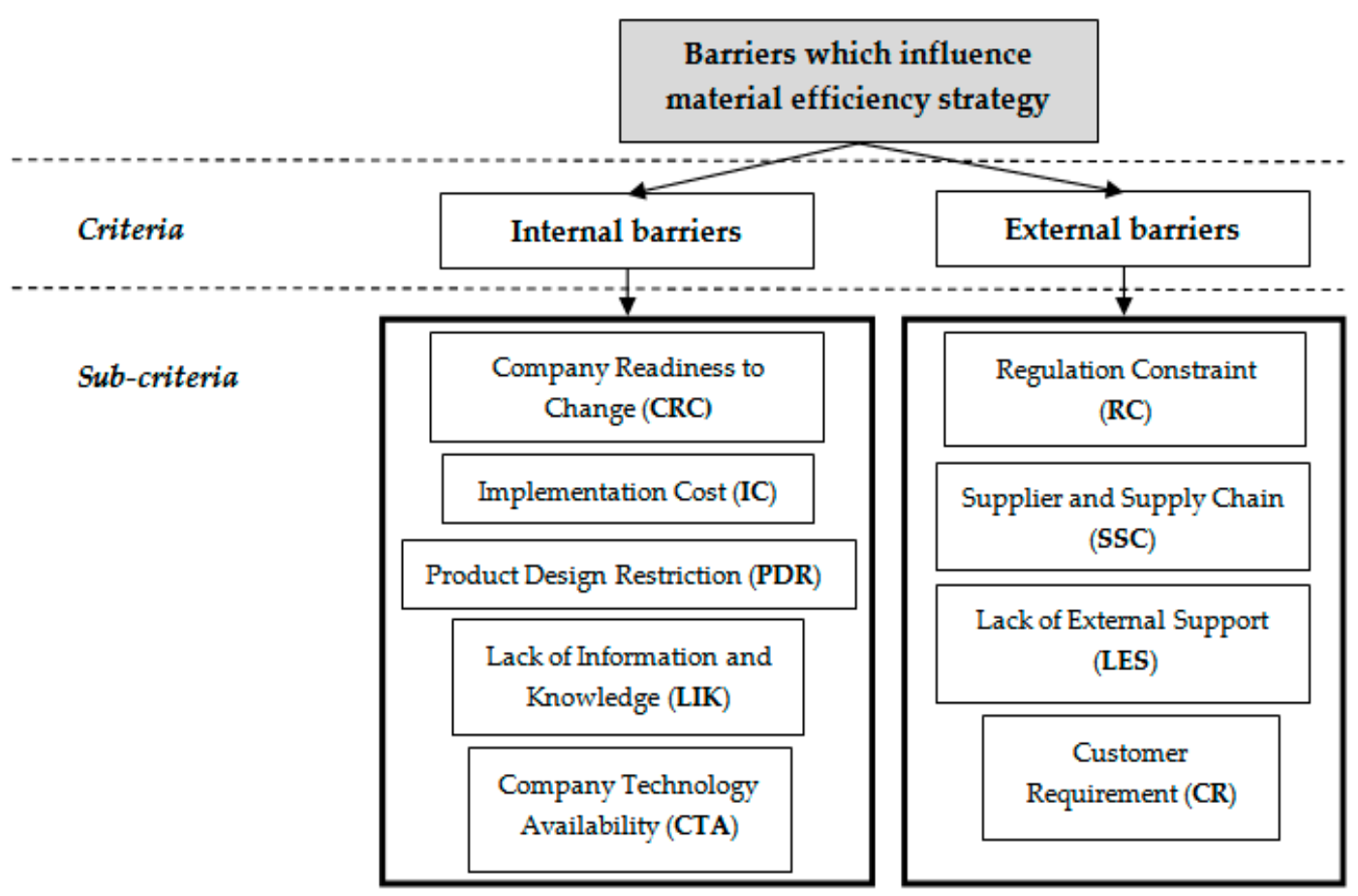

Figure 3. Analytic Hierarchy Process (AHP) framework for barriers to practice material efficiency strategy.

\section{Results}

\subsection{Semi-Structured Interviews}

Based on the results obtained from the qualitative study, the barriers found can be categorized as either internal barriers or external barriers. Five significant barriers fall under the category of internal barriers that could influence the implementation of material efficiency in E\&E companies. These barriers are company readiness to change, implementation cost, product design restriction, lack of information and knowledge, and company technology availability. Similarly, four external barriers were identified as having a possible influence on the implementation of material efficiency practices; namely, regulation constraint, supplier and supply chain, lack of external support and customer requirement. Table 4 shows the list of barriers generated from the semi-structured interviews.

Table 4. List of barriers faced by electrical and electronics (E\&E) companies in practicing material efficiency strategies.

\begin{tabular}{ccc}
\hline & Barrier & Companies \\
\hline \multirow{4}{*}{ Internal Barriers } & Lack of information and knowledge (LIK) & C2 \\
& Product design restriction (PDR) & C3, C4, C5, C6 \\
& Company technology availability (CTA) & C1, C2, C4, C5, C7 \\
& Company readiness to change (CRC) & C1, C2, C3, C5 \\
& Implementation cost (IC) & C1, C4 \\
\hline \multirow{5}{*}{ External Barriers } & Regulation constraint (RC) & C1, C2, C3, C5 \\
& Supplier and supply chain (SSC) & C1, C3, C5 \\
& Lack of external support (LES) & C3 \\
& Customer requirement (CR) & C4, C5, C6 \\
\hline
\end{tabular}

\subsection{AHP Results}

An AHP survey was conducted to strengthen the qualitative findings by determining the priority weight for the explored barriers. From the AHP results, the classification of the priority weight was 
made according to the criteria level. Firstly, the results of the main criteria were obtained, which consisted of the internal barriers and external barriers. Next, the sub-criteria for each group were categorized separately under internal barriers and external barriers. A total of six pairs of sub-criteria evaluation for internal barriers and ten pairs of comparison for external barriers were identified.

The obtained data were then transformed into a pairwise comparison matrix to structure the judgment consistency for the barriers, and compute the eigenvectors, consistency ratio and index. The evaluation was only conducted for the criteria and sub-criteria levels, and no alternatives were measured in the constructed AHP framework. The analysis of the AHP survey was conducted using Expert Choice software, as shown in Table 5, which illustrates the prioritized barriers faced by E\&E companies in practicing a material efficiency strategy. The results show that external barriers had a weight of 0.56 compared to the internal barriers weight of 0.44 . Both the internal and external barrier analyses achieved a comparison consistency ratio of less than 0.01 . For internal barriers, the company technology availability (CTA) was identified as the biggest barrier with a score of 0.253 followed by the implementation cost (IC) with a local weight of 0.235 . The remaining barriers were product design restriction (PDR) with a score of 0.214 , lack of information and knowledge (LIK) with a score of 0.172 and company readiness to change (CRC) with a score of 0.126 . For the external barriers, the largest AHP score was for the customer requirement (CR) at 0.43 , followed by lack of external support (LES) at 0.231 . The remaining external barriers were regulation constraint (RC), which scored 0.198 and the supplier and supply chain (SSC), which scored 0.141. The overall ranking of the barriers regardless of whether they are internal or external can be determined using the global weight, and can be ranked as follows: CR (0.241), LES (0.129), CTA (0.111), RC (0.110), IC (0.104), PD (0.094), SSC (0.079), LIK (0.076), and CRC (0.055).

Table 5. Local and global weights of all barrier categories.

\begin{tabular}{cccccc}
\hline $\begin{array}{c}\text { Barrier } \\
\text { Category } \\
\text { (Criteria) }\end{array}$ & $\begin{array}{c}\text { Relative } \\
\text { Local Weight } \\
\text { of Criteria }\end{array}$ & Barrier (Sub-Criteria) & $\begin{array}{c}\text { Relative Local } \\
\text { Weight of } \\
\text { Sub-Criteria }\end{array}$ & $\begin{array}{c}\text { Global } \\
\text { Weights }\end{array}$ & Rank \\
\hline \multirow{5}{*}{ Internal } & 0.44 & Company technology availability (CTA) & 0.253 & 0.111 & 3 \\
barriers & 0.44 & Implementation cost (IC) & 0.235 & 0.104 & 5 \\
& 0.44 & Product design restriction (PD) & 0.214 & 0.094 & 6 \\
& 0.44 & Lack of information and knowledge (LIK) & 0.172 & 0.076 & 8 \\
\hline \multirow{3}{*}{ External } & 0.44 & Company readiness to change (CRC) & 0.126 & 0.055 & 9 \\
barriers & 0.56 & Customer requirement (CR) & 0.43 & 0.241 & 1 \\
& 0.56 & Lack of external support (LES) & 0.231 & 0.129 & 2 \\
& 0.56 & Regulation constraint (RC) & 0.198 & 0.110 & 4 \\
\hline
\end{tabular}

\subsection{Discussion}

Past empirical studies have shown that understanding the barriers in practicing material efficiency is necessary to help the industry's decision-makers formulate appropriate manufacturing solutions. Thus, this requirement forms the key objective of this paper to identify and evaluate the barriers faced by the E\&E sector in Malaysia. Detailed discussions concerning the barriers identified in this study are provided in the following sections.

\subsubsection{Customer Requirement}

Although fulfilling the customer requirement is a regular driver for environmental strategies [20,35-38], to some extent, it can become a barrier in the implementation of environmental strategies [6]. In our study, we found that E\&E companies emphasized that the customer requirement constitutes a significant barrier that restrains them from practicing material efficiency. For example, designing an electronic product using green materials is challenging and is considered a difficult task as not all customers prefer products made from recovered materials. In addition, many customers associate virgin materials with product quality. One respondent mentioned: "We do not use recycled materials 
extensively, because our material selection is based on the customer requirements. So we cannot dictate because we have to make what the customers want. We do not design first, then find the customer"-C4. Furthermore, in other sectors, such as in the food industry, fulfilling food safety and quality are the highest priority compared to environmental standards [39].

\subsubsection{Lack of External Support}

The second barrier in implementing material efficiency is the lack of external support. External support in this study refers to that given by third parties, such as local government, local recyclers, industry experts or consultants. The government can be a motivating source by providing advice, subsidies and tax reduction incentives to encourage manufacturers and suppliers to implement environmental strategies [6,38]. If limited support is given by the local government, the implementation of environmental practices could be ineffective [39]. In this study, it was found that some of the companies interviewed highlighted that the government support in encouraging environmental practices is very limited, specifically in terms of the recycling infrastructure. The facilities and technology to manage e-waste are still in their infancy in Malaysia, and thus constitute a great challenge to E\&E companies, particularly in terms of green product design. Pajunen et al. [6] argued that a lack of support from local recyclers could reduce the momentum of manufacturers in terms of the efficient use of materials. This could be attributed to the limited technology and techniques to process e-waste. Furthermore, for developing nations, such as Malaysia, recyclers are less exposed to the right approach and knowledge for dealing with industrial waste $[4,6]$. The lack of industry experts and consultants to assist manufacturers and recyclers is another reason that contributes to poor external support. One of the companies mentioned that they lack support from specific parties, such as material efficiency consultants: "Probably not in Malaysia but in Europe I know they have [ ... ] many universities and research institutes come out with new software, and new ways to support the implementation of environmental strategy activities [in manufacturing companies], they are all in Europe"-C3.

\subsubsection{Company Technology Availability}

Technology availability in a company is an important factor to enable the efficient use of materials, e.g., the use of automation systems and robotics could ease the handling of materials and reduce product damage due to mishandling [40]. However, in many manufacturing industries, it is commonly found that outdated machinery is still in use. The use of obsolete technology can generate more solid waste and increase energy consumption. From the interviews with the companies, it was found that some E\&E companies still use old machinery even though they realize that such machines are not efficient. The main reasons given are the high costs associated with purchasing new machines, slow return on investment, especially for expensive machines, and problems concerning the readjustment of operation flow [41]. For example, the solid waste generation during wafer machining is due to the limitations of the clamping jig, which requires a large margin space. In addition, the lack of automated or robotic systems to pick and place the raw materials could cause material damage due to improper material handling by the human operators. For processing nanomaterials, not every manufacturer has suitable machinery or nanotechnology; therefore, they may not able to reduce material consumption by introducing non-type products, such as multiple function chipsets. As a result, optimum material use is difficult to achieve, especially for products that require complex manufacturing processes [20]. This situation can be viewed through the following interview response: "We don't [practice material efficiency] because our machine is fixed, everything is fixed, so we can't do much material saving. If you want to do the saving, you are going to need to change everything"- $\mathrm{C} 2$.

\subsubsection{Regulation Constraint}

Various environmental regulations aim to reduce the environmental impact and promote environmentally conscious manufacturing [6]. In the E\&E sector, the most common directives that must be complied with are the RoHS and WEEE directives [42]. Such compliance is required to ensure 
a significant reduction in the utilization of hazardous substances and the generation of dangerous solid waste. However, regulations can be considered as both drivers and barriers in practicing an environmental strategy $[6,27,37]$. For instance, most respondents of the AHP survey regard regulations as a compulsory requirement albeit they are difficult to fulfil, particularly for those stringent policies that make product design more complicated. Other contributing reasons are difficulty in sourcing green materials [1], lack of government certification of recycled materials [14], and the low demand for green materials, such as recycled materials [14]. Some of the companies in this study mentioned that the available regulations have limited their choice in selecting an appropriate manufacturing process or alternative materials. For instance, Company C3 noted " ... using the green materials is costly, but if you are not doing so you will lose the business because you cannot penetrate into customers' countries. You need to fulfil all those standards first!". Thus, sometimes, manufacturing companies are unable to sell their products on the international market due to failure to comply with the regulations.

\subsubsection{Implementation Cost}

For manufacturing companies, implementing a new strategy requires investment, especially in terms of purchasing new technology, acquiring permits, and material sourcing. From the interviews, it was found that the participating companies are less interested in investing in new business strategies that they are not familiar with. These investments include the cost of obtaining approvals and permits, such as environmental standards [6], the cost of upgrading machinery, and the cost of substituting green materials $[1,14,43]$. Several companies stated that investment in technology is the most critical issue because the initial investment is high $[1,18,19]$, while the payback time is very long [6]. From the interview results, two companies mentioned that acquiring permits or adhering to standards requires huge investment cost. One of the companies mentioned "let us say that now we have a lot of alternatives, such as environmental friendly materials, but we cannot use them because the price is much more expensive, so we are deterred by the pricing" $-\mathrm{C} 4$. However, in other countries, such as China, the implementation cost is the primary barrier towards the adoption of environmental strategies because they focus on a cheap price oriented business model, and, therefore, to acquire expensive technology and spend highly to comply with environmental standards constitute their main problem [44].

\subsubsection{Product Design Restriction}

In this study, E\&E companies were found to be facing product design restrictions in the implementation of material efficiency. Some E\&E manufacturers have difficulty in substituting with recycled materials, as it may influence the product quality and functionality, and may result in reduced demand from consumers. These findings are in agreement with past studies by Allwood et al. [1], and Peck and Chipman [3]. On the other hand, greener materials (lead free materials, mercury and cadmium free substances) are strictly required to fulfil RoHS and WEEE directives, as mentioned by Chiang et al. [45]. However, to a certain extent, E\&E companies mentioned that not all types of product are applicable for redesign because they may incur additional cost in terms of the existing production process. For instance, company C 5 said "In the design context, there are some limitations if you design your product using green materials, there could also be some limitations with the processing technology". This finding is similar to the barriers discussed in a previous study in which changes in product design could be complex and difficult as they may also impact on the manufacturing process $[1,8]$.

\subsubsection{Supplier and Supply Chain}

It was found that local suppliers are less capable in terms of supplying green materials. For that reason, E\&E manufacturers need to source the green materials from overseas suppliers, which are usually more expensive. One of the reasons is that local suppliers lack the knowledge and technology to produce green materials. This finding is consistent with the challenges raised by Abdul Rashid and Evans [25], and Walker et al. [27] whereby poor commitment from suppliers to supply the required materials could discourage the implementation of environmental strategies. Furthermore, not all 
local suppliers are certified in terms of the environmental management standards, such as ISO14001. This finding confirmed the emerging trend reported by [8], which has rarely been discussed in past literature. One company mentioned " ... at present, not many suppliers are able to supply green materials, so we need to use a lot of European and American suppliers to supply us with parts because some of the Asian suppliers have yet to convert their parts to become lead free"-C3.

Another issue faced by E\&E manufacturing companies is an unreliable supply chain. This finding further confirmed that an unreliable supply chain is one of the barriers that can cause poor implementation of environmental practices, as mentioned by Abdul Rashid and Evans [25], and Zhu and Geng [46]. For E\&E companies, green materials are hard to source in developing countries such as Malaysia. Therefore, most manufacturers either import raw materials from other countries or source them from very limited local suppliers.

\subsubsection{Lack of Information and Knowledge}

To achieve material efficiency, engineers need to improve their technical knowledge, especially in terms of the use of materials, product design, and the manufacturing process [1]. From the interviews it was found that some E\&E companies were not capable of formulating a material efficiency solution. For example, they do not know what can be done to achieve material efficiency. This might be because some of the interviewed companies do not have a research and development (R\&D) department, and have little experience in terms of material efficiency. In addition, local managers in Malaysia are not given full authority to make decisions on production improvements. Most of these companies are limited by company policies [6], and, as a result, companies become less competitive. It has also been proven in empirical studies that manufacturers from developing countries fail to implement material efficiency concepts because of limited knowledge in terms of environmental strategy adoption [20]. For instance, Company C2 highlighted that "We need to compete with China, Taiwan, the US, Germany, Europe, and Singapore, but we do not have the skills or knowledge to compete, especially in material efficiency".

\subsubsection{Company Readiness to Change}

Implementing environmental strategies requires an organization to change in terms of either the context of management or the technical aspects [38]. However, not every change is easy and some changes require complicated adjustments, high cost investment and a strong commitment from the company's stakeholders. Currently, E\&E companies are most familiar with energy efficiency benefits and requirements. Therefore, to implement a new strategy, such as material efficiency practices, some of the participating E\&E companies mentioned that they are troublesome and time consuming. This result is not surprising as empirical studies have shown that manufacturing organizations in Asian countries are less ready to carry out environmentally-conscious manufacturing [47].

From another point of view, E\&E companies are less ready to implement material efficiency because they are less confident of the benefits that the new changes will bring. Pajunen et al. [6] agreed that unproven scientific results have reduced the willingness of companies to explore material efficiency. Furthermore, manufacturers are afraid that material efficiency strategies may increase the company's financial burden. For example, implementing environmental strategies requires manufacturers spending more on sourcing for expensive raw materials [48]. As a result, it is not uncommon for a company to stick to conventional approaches that are considered the safest. One of the E\&E companies said that it is less willing to change unless required by the market " .. you know, when it comes to the environmental issue, when it doesn't hit us, we don't take action. I think the Malaysian industries have a serious issue, we are not competitive as we are not quick enough to change"-C2.

\section{Conclusions}

In this study, the identified barriers are categorized into internal and external barriers. From the empirical analysis, a total of nine barriers that influence the implementation of material efficiency were shortlisted. Each barrier influences the practice of material efficiency in significantly different 
ways. The priority orders of the barriers in practicing material efficiency are ranked as follows: customer requirement; lack of external support; company technology availability; regulation constraint; implementation cost; product design restriction; supplier and supply chain; lack of information and knowledge; and company readiness to change.

It was found that E\&E companies face rather similar barriers to those stated in the literature in terms of implementing material efficiency strategies. Unsurprisingly, it was discovered that E\&E companies find themselves challenged by the rapid changes in technology demand. The potential reasons for this include customers demanding various product functions, fluctuation in the supply of global resources and an increase in the environmental declarations concerning material usage. In this study, it was found that company technology availability is the biggest barrier to an organization achieving material efficiency. This obstacle could be related to the high cost of purchase of new technology, the slow return on investment, and because product outsourcing is much cheaper and less troublesome. Company readiness to change was found to be the least significant barrier because the requirements for material efficiency are well understood by E\&E companies. For example, E\&E companies are required to comply with RoHS and WEEE to ensure that their products do not contain more than the permitted levels of hazardous substances.

Understanding the barriers is important in determining the appropriate action to achieve material efficiency. For example, in tackling product design restrictions, E\&E companies can consider seeking the help of material efficiency experts or experienced suppliers to comply with stringent environmental regulations. If the company is not ready to change, the management should consult external experts, such as lean experts, to provide effective courses for their employees to increase the awareness of environmental manufacturing. Thereafter, a new business model could possibly be implemented in the future in the E\&E sector, such as offering a longer warranty claim for their products and increasing the service aspect of the business with the supply of longer life products.

Although the barriers determined in this study seem to be similar to those found in the literature, the contextual study of E\&E companies in Malaysia enables other practitioners to experience the challenges of implementing material efficiency with more insightful views. By knowing the weightage of barriers in practicing material efficiency strategies, E\&E manufacturers can formulate and prioritize appropriate solutions that are unique and fit the local scenario in Malaysia. These findings are extremely useful in helping the key-informants to make any important decision, especially in terms of achieving a balanced trade-off. This will position them with a clearer direction to achieve material efficiency, to establish their own R\&D center, work closely with their suppliers, or to standardize their design. The data and observations gathered in this study are highly promising for forming insightful findings that can explain the current material efficiency understanding and situation in E\&E companies in Malaysia. Consequently, the results of this study could form the basis for the development of important indicators for future research, such as the establishment of a material efficiency benchmarking checklist for similar industries.

Acknowledgments: The authors would like to thank the University of Malaya for funding this research under the University of Malaya Research Grant (RP033B-15AET).

Author Contributions: Fu Haw Ho, Salwa Hanim Abdul-Rashid and Raja Ariffin Raja Ghazilla designed the study, developed the methodology, performed the analysis, and wrote the manuscript. Fu Haw Ho collected the data.

Conflicts of Interest: The authors declare no conflicts of interest.

\section{Appendix A. Example Interview Protocols}

(1) What are the challenges faced by your company in achieving sustainable manufacturing?

(2) What are the barriers or difficulties faced by your company in using the materials efficiently?

(3) Is there any problem faced in reducing the material usage in the product design phase?

(4) Is there any problem faced in reducing the material usage in your company's production?

(5) How does you company overcome the mentioned barriers in using materials efficiently? 


\section{References}

1. Allwood, J.M.; Ashby, M.F.; Gutowski, T.G.; Worrell, E. Material efficiency: A white paper. Resour. Conserv. Recycl. 2011, 55, 362-381. [CrossRef]

2. Lilja, R. From waste prevention to promotion of material efficiency: Change of discourse in the waste policy of Finland. J. Clean. Prod. 2009, 17, 129-136. [CrossRef]

3. Peck, M.; Chipman, R. Industrial Energy and Material Efficiency: What Role for Policies? Industrial Development for the Twenty-First Century: Sustainable Development Perspectives; United Nations Division for Sustainable Development: New York, NY, USA, 2007; pp. 333-385.

4. Allwood, J.M.; Ashby, M.F.; Gutowski, T.G.; Worrell, E. Material efficiency: Providing material services with less material production. Philos. Trans. R. Soc. A 2013. [CrossRef] [PubMed]

5. Lifset, R.; Eckelman, M. Material efficiency in a multi-material world. Philos. Trans. R. Soc. A 2013, 371, 20120002. [CrossRef] [PubMed]

6. Pajunen, N.; Watkins, G.; Wierink, M.; Heiskanen, K. Drivers and barriers of effective industrial material use. Miner. Eng. 2012, 29, 39-46. [CrossRef]

7. Malaysia Statistics Department. Available online: https://www.statistics.gov.my (accessed on 5 August 2016).

8. Ministry of International Trade and Industry. Available online: http://www.miti.gov.my/index.php/pages/ view/3132 (accessed on 5 August 2016).

9. Humphries, M. Rare Earth Elements: The Global Supply Chain. Available online: https://stuff.mit.edu/afs / athena/course/12/12.000/www/m2016/pdf/R41347.pdf (accessed on 7 October 2016).

10. Rare Earth Weekly Review Feb 25-28, 2015. Available online: http://cn.info-re.com/editor/attached/file/ 20150228/20150228165102_69342.pdf (accessed on 25 August 2016).

11. Osibanjo, O.; Nnorom, I.C. The challenge of electronic waste (e-waste) management in developing countries. Waste Manag. Res. 2007, 25, 489-501. [CrossRef] [PubMed]

12. Abdul Rashid, S.H. An Investigation into the Material Efficiency Practices of UK Manufacturers. Ph.D. Thesis, Cranfield University, Cranfield, UK, 2009.

13. Worrell, E.; van Sluisveld, M.A. Material efficiency in Dutch packaging policy. Philos. Trans. R. Soc. A 2013, 371, 2012004. [CrossRef] [PubMed]

14. Ashby, M.F. Materials and the Environment: Eco-Informed Material Choice; Butterworth-Heinemann Publisher: Oxford, UK, 2012; pp. 415-436.

15. Abdul Rashid, S.; Evans, S.; Longhurst, P. A comparison of four sustainable manufacturing strategies. Int. J. Sustain. Eng. 2008, 1, 214-229. [CrossRef]

16. Lilja, R. Negotiated environmental agreements in promoting material efficiency in industry-First steps in Finland. J. Clean. Prod. 2009, 17, 863-872. [CrossRef]

17. Hillary, R. Environmental management systems and the smaller enterprise. J. Clean. Prod. 2004, 12, 561-569. [CrossRef]

18. Halme, M.; Anttonen, M.; Kuisma, M. Business Models for Material Efficiency Services. In Factor X; Springer: Dutch, The Netherlands, 2014; pp. 193-216.

19. Moors, E.H.; Mulder, K.F.; Vergragt, P.J. Towards cleaner production: Barriers and strategies in the base metals producing industry. J. Clean. Prod. 2005, 13, 657-668. [CrossRef]

20. Luken, R.; Van Rompaey, F. Drivers for and barriers to environmentally sound technology adoption by manufacturing plants in nine developing countries. J. Clean. Prod. 2008, 16, S67-S77. [CrossRef]

21. Hanssen, O.J.; Olsen, A.; Møller, H.; Rubach, S. National indicators for material efficiency and waste minimization for the Norwegian packaging sector 1995-2001. Resour. Conserv. Recycl. 2003, 38, 123-137. [CrossRef]

22. Hekkert, M.P.; Joosten, L.A.J.; Worrell, E. Reduction of $\mathrm{CO}_{2}$ emissions by improved management of material and product use: The case of transport packaging. Resour. Conserv. Recycl. 2000, 30, 1-27. [CrossRef]

23. Lodenius, M.; Heino, E.; Viljakainen, S. Introducing a new model for material savings in the Finnish paper industry. Resour. Conserv. Recycl. 2009, 53, 255-261. [CrossRef]

24. Hekkert, M.; Vandenreek, J.; Worrell, E.; Turkenburg, W. The impact of material efficient end-use technologies on paper use and carbon emissions. Resour. Conserv. Recycl. 2002, 36, 241-266. [CrossRef]

25. Abdul Rashid, S.H.; Evans, S. Supply chain constraints in practising material efficiency strategies: Evidence from UK companies. In Sustainable Manufacturing; Springer: Berlin/Heidelberg, Germany, 2012; pp. 237-241. 
26. Luthra, S.; Kumar, V.; Kumar, S.; Haleem, A. Barriers to implement green supply chain management in automobile industry using interpretive structural modeling technique: An Indian perspective. J. Ind. Eng. Manag. 2011, 4, 231-257. [CrossRef]

27. Walker, H.; di Sisto, L.; McBain, D. Drivers and barriers to environmental supply chain management practices: Lessons from the public and private sectors. J. Purch. Suppl. Manag. 2008, 14, 69-85. [CrossRef]

28. Abdul Rashid, S.H.; Fu-Haw, H.; Bahreinine, A.; Raja Ghazilla, R.A. Barriers in Practicing Material Efficiency Strategy in Malaysian Electrical and Electronic Industry: Practitioners Perspective. In Proceedings of the 10th Global Conference on Sustainable Manufacturing: Towards Implementing Sustainable Manufacturing, Istanbul, Turkey, 31 October-2 November 2012.

29. Creswell, J.W.; Clark, V.L.P. Designing and Conducting Mixed Methods Research; Sage Publications: Thousand Oaks, CA, USA, 2007.

30. Yin, R. Case Study Research: Design and Methods, 3rd ed.; Sage Publications: Thousand Oaks, CA, USA, 2003.

31. Voss, C.; Tsikriktsis, N.; Frohlich, M. Case research in operations management. Int. J. Oper. Prod. Manag. 2002, 22, 195-219. [CrossRef]

32. Blaikie, N. Designing Social Research; Polity Press: Cambridge, UK; Malden, MA, USA, 2009.

33. Saaty, T.L.; Vargas, L.G. Models, Methods, Concepts \& Applications of the Analytic Hierarchy Process; Kluwer Academic Publishers: Norwell, MA, USA, 2001.

34. Saaty, T.L. Decision Making for Leaders; RWS Publications: Pittsburgh, PA, USA, 2008.

35. Honkasalo, N.; Rodhe, H.; Dalhammar, C. Environmental permitting as a driver for eco-efficiency in the dairy industry: A closer look at the IPPC directive. J. Clean. Prod. 2005, 13, 1049-1060. [CrossRef]

36. Agamuthu, P.; Khidzir, K.M.; Hamid, F.S. Drivers of sustainable waste management in Asia. Waste Manag. Res. 2009, 27, 625-633. [CrossRef] [PubMed]

37. Diabat, A.; Govindan, K. An analysis of the drivers affecting the implementation of green supply chain management. Resour. Conserv. Recycl. 2011, 55, 659-667. [CrossRef]

38. Lee, S.Y. Drivers for the participation of small and medium-sized suppliers in green supply chain initiatives. Suppl. Chain Manag. 2008, 13, 185-198. [CrossRef]

39. Massoud, M.A.; Fayad, R.; El-Fadel, M.; Kamleh, R. Drivers, barriers and incentives to implementing environmental management systems in the food industry: A case of Lebanon. J. Clean. Prod. 2010, 18, 200-209. [CrossRef]

40. Koc, T.; Bozdag, E. The impact of AMT practices on firm performance in manufacturing SMEs. Robot. Comput. Integr. Manuf. 2009, 25, 303-313. [CrossRef]

41. Melanen, M. Waste minimization in small and medium-sized enterprises-Do environmental management systems help? J. Clean. Prod. 2001, 9, 209-217.

42. Ongondo, F.O.; Williams, I.D.; Cherrett, T.J. How are WEEE doing? A global review of the management of electrical and electronic wastes. Waste Manag. 2011, 31, 714-730. [CrossRef] [PubMed]

43. Worrell, E.; Faaij, A.P.C.; Phylipsen, G.J.M.; Blok, K. An approach for analysing the potential for material efficiency improvement. Resour. Conserv. Recycl. 1995, 13, 215-232. [CrossRef]

44. Chiang, S.Y.; Wei, C.C.; Chiang, T.H.; Chen, W.L. The key indicators of lead-free manufacturing in electronics industry in Taiwan and Japan. In Proceedings of the International Conference on IEEE Management and Service Science, Wuhan, China, 20-22 September 2009; pp. 1-6.

45. Shi, H.; Peng, S.Z.; Liu, Y.; Zhong, P. Barriers to the implementation of cleaner production in Chinese SMEs: Government, industry and expert stakeholders' perspectives. J. Clean. Prod. 2008, 16, 842-852. [CrossRef]

46. Zhu, Q.; Geng, Y. Drivers and barriers of extended supply chain practices for energy saving and emission reduction among Chinese manufacturers. J. Clean. Prod. 2013, 40, 6-12. [CrossRef]

47. Thiruchelvam, M.; Kumar, S.; Visvanathan, C. Policy options to promote energy efficient and environmentally sound technologies in small-and medium-scale industries. Energy Policy 2003, 31, 977-987. [CrossRef]

48. Byggeth, S.; Hochschorner, E. Handling trade-offs in ecodesign tools for sustainable product development and procurement. J. Clean. Prod. 2006, 14, 1420-1430. [CrossRef]

(C) 2016 by the authors; licensee MDPI, Basel, Switzerland. This article is an open access article distributed under the terms and conditions of the Creative Commons Attribution (CC-BY) license (http://creativecommons.org/licenses/by/4.0/). 